\title{
Small Cell Ovarian Carcinomas - Characterisation of Two Rare Tumor Entities
}

\author{
Kleinzellige Ovarialkarzinome - \\ Charakterisierung von 2 seltenen Tumorentitäten
}

Authors

Affiliation
K. Münstedt, R. Estel, T. Dreyer, A. Kurata, A. Benz

Frauenklinik, Universitätsklinikum Gießen, Gießen

Key words
ovarian cancer
ovarian tumor
ovary
Schlüsselwörter
Ovarmalignom
Ovar
benigne Ovartumoren

received 20.2.2013

revised 28.4.2013

accepted 29.4.2013

Bibliography

DOI http://dx.doi.org/

$10.1055 / \mathrm{s}-0032-1328658$

Geburtsh Frauenheilk 2013; 73 :

698-704 ๑ Georg Thieme

Verlag KG Stuttgart · New York . ISSN 0016-5751

\section{Correspondence}

\section{Prof. Karsten Münstedt}

Universitätsklinikum Gießen

Frauenklinik

Klinikstraße 33

35435 Gießen

karsten.muenstedt@

gyn.med.uni-giessen.de

\section{Abstract \\ $\nabla$}

Objective: Small cell ovarian carcinomas (SCOC) are differentiated into two types: hypercalcaemic (SCOCHT) and pulmonary (SCOCPT). Unfortunately, little is known about pulmonary-type small cell ovarian carcinoma.

Study Design: We carried out a systematic analysis of all available reports in the literature on individual cases of SCOCHT and SCOCPT.

Results: We found that patients with SCOCPT were significantly older than those with SCOCHT. Vimentin and chromogranin detection by immunohistochemistry allow good differentiation between the two types. Interestingly, SCOCPT but not SCOCHT was found to be associated with other benign and malignant ovarian tumours in about $44 \%$ of cases. Although the percentage of R0/R1 resections was high $(\sim 74 \%)$, survival was poor; even in patients with disease limited to the ovaries (stage Ia and $\mathrm{Ib}$ ) the recurrence rate was $40 \%$. Chemotherapy with etoposide or anthracyclines could be useful.

Conclusion: Taking the limitations of our study such as its retrospective nature into account and based on the results from studies of small cell carcinomas originating from other tumour sites, we conclude that treatment of SCOCPT should be based on the therapies used to treat other small cell carcinomas. Surgery is appropriate, especially in very early stages of disease, but chemotherapy should not be omitted. Newer concepts such as treatment with somatostatin analogues could help to control symptoms and stabilise some slow-growing tumours.

\section{Zusammenfassung \\ $\nabla$}

Einleitung: Es gibt 2 Arten von kleinzelligen Ovarialkarzinomen - die vom hyperkalzämischen (SCOCHT) und die vom pulmonalen Typ (SCOCPT). Leider ist wenig über die Karzinome vom pulmonalen Typ bekannt.

Material und Methode: Wir führten ein systematisches Review aller zur Verfügung stehenden Fälle aus der Literatur zu beiden Tumorentitäten durch.

Ergebnisse: Patientinnen mit SCOCPT waren signifikant älter als diejenigen mit SCOCHT. Vimentin- und Chromogranin-Expression in der Immunohistochemie erlaubte eine gute Unterscheidung zwischen beiden Tumorentitäten. Interessanterweise waren Fälle von SCOCPT, aber nicht solche mit SCOCHT häufig (44\%) assoziiiert mit anderen benignen und malignen Ovarialtumoren. Trotz hoher Rate an R0/R1-Resektionen ( 74\%) war das Überleben der Patientinnen selbst in frühen Tumorstadien (FIGO-Stadium Ia oder Ib) sehr schlecht, und es zeigte sich eine Rezidivrate hier von $40 \%$. Soweit beurteilbar, erschienen Chemotherapien mit Etoposide oder Anthrazyklinen beim pulmonalen Typ sinnvoll.

Schlussfolgerungen: Unter Berücksichtigung der Probleme dieses Studienansatzes und im Vergleich zu Studiendaten zu kleinzelligen Tumoren anderer Lokalisationen kann man schließen, dass sich die Behandlung des SCOCPT allgemein an den dort gewonnenen Erkenntnissen orientieren sollte. Operationen sind angebracht, insbesondere in den frühen Stadien, aber Chemotherapie darf niemals unterlassen werden. Möglicherweise sind neue Behandlungsansätze wie die Behandlung mit Somatostatin-Analoga geeignet, die Erkrankung und deren Symptomatik positiv zu beeinflussen. 


\section{Key Message box}

Small cell ovarian carcinomas of the pulmonary and hypercalcaemic type are two entities with a poor prognosis and may require different treatment concepts than those used for the more common epithelial tumors. Surgery seems to be effective only in the very early stages.

\section{Abbreviations \\ $\checkmark$ \\ SCOCHT small cell ovarian carcinoma of the hypercalcaemic type \\ SCOCPT small cell ovarian carcinoma of the pulmonary type}

\section{Introduction}

Ovarian carcinomas are quite common. Clear treatment guidelines have been established and include radical surgery and combination chemotherapy with paclitaxel, carboplatinum and bevacizumab in the advanced stage of disease. The role of prophylactic surgery in women at risk for familial breast or ovarian cancer has been defined [1].

Small cell ovarian carcinoma (SCOC) is a rare neoplasm divided histologically into the subgroups SCOC of the hypercalcaemic type (SCOCHT; 8041/3) and SCOC of the pulmonary type (SCOCPT; 8041/3) [2]. They comprise about $1 \%$ of all ovarian neoplasms and are distinguished by their growth patterns and immunoprofiles. SCOCHT generally stains for epithelial membrane antigens whereas SCOCPT is typically positive for neuron-specific enolase and, in some cases, chromogranin [2]. However, little is known about SCOCPT and there are no specific treatment guidelines for this tumour type although the prognosis is known to be poorer than the prognosis for common epithelial ovarian carcinomas. Primary ovarian small cell carcinomas of the pulmonary type histologically resemble their counterparts in other organs. They are composed of small cells with little cytoplasm and oval to spindle-shaped nuclei [3]. Recently, we characterised all published cases of SCOCHT [4]. This allowed some conclusions to be made on how treatment of this entity could be improved. However, a systematic review and analysis of all reported cases of SCOCPT has not previously been done. The aim of this study was to assess the cases of SCOCPT in the literature and compare the characteristics of this entity with those of SCOCHT.

\section{Materials and Methods}

$\nabla$

\section{Search strategy}

To identify articles on small cell ovarian carcinoma, we searched Medline and PubMed using the search terms "small cell carcinoma", "ovary", "ovarian" and cross-checked the references from retrieved articles. We used the search engine google.de for further investigations.

The search covered articles published between February 1975 and July 2012. All articles were evaluated for individualised patient data on clinical presentation, preoperative diagnostics, surgical and adjuvant therapies as well as follow-up data. In addition to papers in English, papers in French, Italian, Polish, Japanese and Korean were evaluated.
Table 1 Patient characteristics and immunohistochemical expression patterns of SCOCPT and SCOCHT.

\begin{tabular}{|c|c|c|}
\hline Variable & SCOCPT & SCOCHT \\
\hline \multicolumn{3}{|l|}{ Age (years) } \\
\hline > Mean & 47.8 & 22.8 \\
\hline - SD & 17.1 & 9.8 \\
\hline \multicolumn{3}{|c|}{ Distribution of stage at diagnosis $\left(\%\left[\mathrm{n}+/ \mathrm{n}_{\text {total }}\right]\right)$} \\
\hline$>1$ & $42.9(9 / 21)$ & $46.8(52 / 111)$ \\
\hline$>2$ & $4.8(1 / 21)$ & $11.7(13 / 111)$ \\
\hline$>3$ & $47.6(10 / 21)$ & $37.8(42 / 111)$ \\
\hline$>4$ & $4.8(1 / 21)$ & $3.6(4 / 111)$ \\
\hline \multicolumn{3}{|c|}{ Clinical symptoms at the time of presentation (\% $\left.\left[n+/ n_{\text {total }}\right]\right)$} \\
\hline > overall & $94.3(33 / 35)$ & $97.6(80 / 82)$ \\
\hline \multicolumn{3}{|l|}{ Specific } \\
\hline nausea and vomiting & $60.0(21 / 35)$ & $25.6(21 / 82)$ \\
\hline - palpable mass & $48.6(17 / 35)$ & $10.9(9 / 82)$ \\
\hline $\begin{array}{l}\text { increase in waist } \\
\text { circumference }\end{array}$ & $34.3(12 / 35)$ & $24.4(20 / 82)$ \\
\hline - lower abdominal pain & $22.9(8 / 35)$ & $26.8(22 / 82)$ \\
\hline - stomach ache & $20.0(7 / 35)$ & $45.1(37 / 82)$ \\
\hline - fatigue & $20.0(7 / 35)$ & $8.5(7 / 82)$ \\
\hline urinary pain & $17.1(6 / 35)$ & $7.3(6 / 82)$ \\
\hline - amenorrhoea, spotting & $11.4(4 / 35)$ & $8.5(7 / 82)$ \\
\hline - acute abdomen & $8.6(3 / 35)$ & $3.7(3 / 82)$ \\
\hline - back pain & $5.7(2 / 35)$ & $7.3(6 / 82)$ \\
\hline constipation & $5.7(2 / 35)$ & $18.3(15 / 82)$ \\
\hline D weight loss & $5.7(2 / 35)$ & $17.0(14 / 82)$ \\
\hline \multicolumn{3}{|c|}{ Serum tumour markers at presentation $\left(\%\left[\mathrm{n}+/ \mathrm{n}_{\text {total }}\right]\right)$} \\
\hline - hypercalcaemia & $0.0(0 / 11)$ & $67.1(57 / 85)$ \\
\hline - parathormone & not reported & $27.3(3 / 11)$ \\
\hline - CA 125 & $82.4(14 / 17)$ & $80.0(28 / 35)$ \\
\hline$\checkmark$ CA 153 & $0.0(0 / 1)$ & $0.0(0 / 2)$ \\
\hline > CA 19-9 & $37.5(3 / 8)$ & $25.0(1 / 4)$ \\
\hline$\checkmark$ CEA & $36.4(4 / 11)$ & $0.0(0 / 7)$ \\
\hline - NSE & $85.7(6 / 7)$ & not reported \\
\hline$\checkmark \mathrm{SCC}$ & $33.3(1 / 3)$ & not reported \\
\hline$\checkmark$ AFP & $0.0(0 / 7)$ & $0.0(0 / 19)$ \\
\hline \multicolumn{3}{|l|}{ Affected side (\% [n $\left.\left.+/ n_{\text {total }}\right]\right)$} \\
\hline > left & $37.1(13 / 35)$ & $35.5(33 / 93)$ \\
\hline - right & $31.4(11 / 35)$ & $60.2(56 / 93)$ \\
\hline - bilateral & $31.4(11 / 35)$ & $4.3(4 / 93)$ \\
\hline \multicolumn{3}{|c|}{ Mean tumour size and volume } \\
\hline > size $(\mathrm{cm})$ & $13.5(\mathrm{SD} 6.6)$ & $15.2(S D 4.8)$ \\
\hline - volume $\left(\mathrm{cm}^{3}\right)$ & 1449 & 2165 \\
\hline \multicolumn{3}{|c|}{ Association with other tumours $\left(\%\left[n+/ n_{\text {total }}\right]\right)$} \\
\hline > overall & $44.4(16 / 36)$ & $1.8 \%, 2 / 110$ \\
\hline \multicolumn{3}{|l|}{ Specific } \\
\hline $\begin{array}{l}\text { - endometrioid } \\
\text { adenocarcinoma }\end{array}$ & $16.6(6 / 36)$ & - \\
\hline - mucinous carcinoma & $8.3(3 / 36)$ & - \\
\hline - benign teratoma & $8.3(3 / 36)$ & $1.8 \%, 2 / 110$ \\
\hline - Brenner tumours & $5.5(2 / 36)$ & - \\
\hline \multicolumn{3}{|c|}{ Expression of tumour characteristics $\left(\%\left[\mathrm{n}+/ \mathrm{n}_{\text {total }}\right]\right)$} \\
\hline - synaptopodin & $68.4 \%(13 / 19)$ & $50.0 \%(5 / 10)$ \\
\hline $\begin{array}{l}\text { neuron-specific } \\
\text { enolase (NSE) }\end{array}$ & $86.4 \%(19 / 22)$ & $80.0 \%(16 / 20)$ \\
\hline $\begin{array}{l}\text { epithelial membrane } \\
\text { antigen (EMA) }\end{array}$ & $55.6 \%(10 / 18)$ & $78.8 \%(26 / 33)$ \\
\hline - chromogranin & $53.3 \%(15 / 28)$ & $9.5 \%(2 / 21)$ \\
\hline - vimentin & $4.8 \%(1 / 21)$ & $93.9 \%(46 / 49)$ \\
\hline - cytokeratin & $68.2 \%(15 / 22)$ & $87.7 \%(50 / 57)$ \\
\hline
\end{tabular}




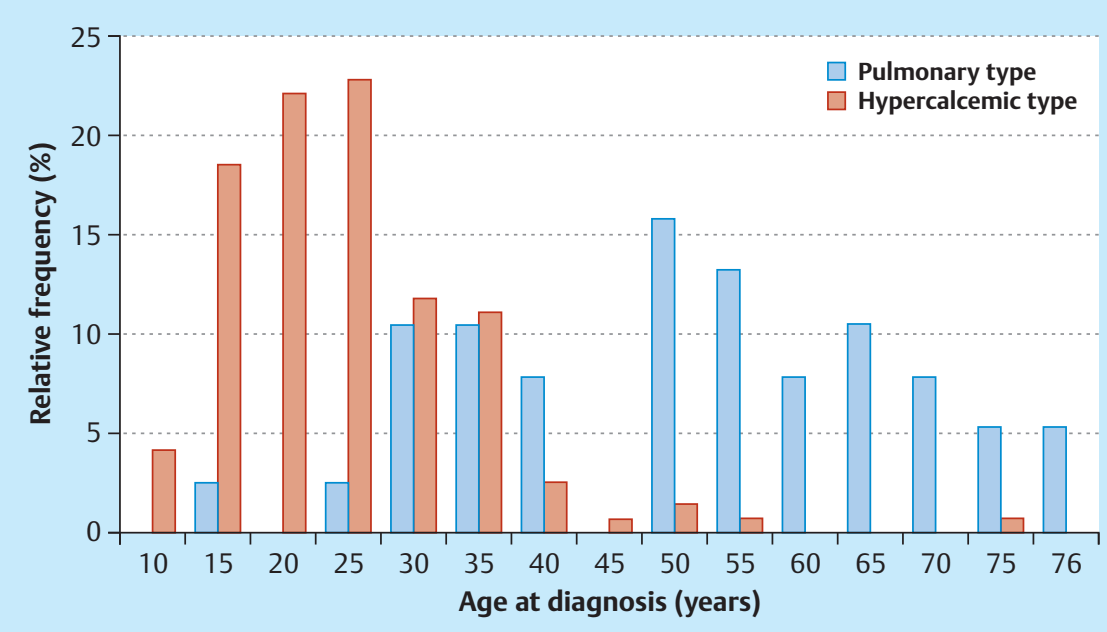

Fig. 1 Age distribution of patients with SCOCPT and SCOCHT $\left(\mathrm{F}_{\text {T-Test }}=25.7, \mathrm{p}<0.001\right)$.

In all, we identified 127 studies which focussed on primary ovarian small cell carcinoma. Papers were excluded if they were about molecular or histological topics $(n=25)$, did not provide sufficient data on individual patients $(n=4)$, or were in a language not included in our research $(n=1)$. Two articles were not accessible by the means available. After excluding these 32 studies, a total of 95 case studies and reports from case series remained with sufficient data on patients (SCOCPT: $n=26$; SCOCHT: $\mathrm{n}=69$ ) [5-99].

Eighty-six of these papers were published as case reports (from 1 to 3 patients) (SCOCPT: $n=25$; SCOCHT: $n=61$ ), and 9 consisted of smaller case series (up to 17 patients) (SCOCPT: $n=1$; SCOCHT: $n=8$ ). One of the cases not published in the literature was reported by the Department of Obstetrics and Gynaecology, Hanau Clinics, Germany, in 2009 as a case report by Hrgovic et al. In total, 182 individual cases were available for analysis (SCOCPT: $\mathrm{n}=38$; SCOCHT: $\mathrm{n}=144$ ).

\section{Statistical analysis}

SPSS software 17.0 (SPSS Inc, Chicago, IL, USA) for Windows ${ }^{\circledR}$ was used for data management and statistical analysis. Actual disease-free survival and overall survival of patients with reported follow-up was estimated using the Kaplan-Meier life-table method. Differences in survival rates were assessed by log-rank test. The Mann-Whitney U-test was used to check for significant differences in quantitative parameters and the chi-square test was used for qualitative variables. Survival time was measured from the date of the initial laparotomy. We compared the data from this analysis to our earlier analysis of small cell ovarian carcinoma of the hypercalcaemic type [3]. A p value below 0.05 $(p<0.05)$ was regarded as indicating a significant difference.

We informed the local ethics committee of the study prior to analysis. The local ethics committee consented to the study on January 15th, 2010 (application number 07/2010).

\section{Results \\ $\nabla$}

Various characteristics are shown and compared in $\bullet$ Table 1. Mean age of patients with SCOCPT was significantly higher than that of patients with SCOCHT $\left(\mathrm{F}_{\mathrm{T}-\mathrm{Test}}=25.7, \mathrm{p}<0.001\right)$. A more detailed age distribution of the two entities is shown in $\bullet$ Fig. 1.
Most patients with either tumour type had clinical symptoms at the time of presentation. A detailed summary of complaints is given in Table 1. Time between onset of symptoms and diagnosis in patients with SCOCPT was 16.1 weeks (SD =14.8), which was much longer compared to that in SCOCHT (4.9 weeks, SD 4.4; $\mathrm{F}_{\mathrm{T} \text {-Test }}=19.1, \mathrm{p}<0.001$ ). At diagnosis, several tumour markers were elevated. CA125 was increased in both tumour entities. Neuron-specific enolase (NSE) and carcinoembryonic antigen (CEA) were more frequently elevated in patients with SCOCPT, whereas hypercalcaemia was not found in patients with SCOCPT but frequently in patients with SCOCHT ( Table 1 ).

We also found evidence that SCOCHT occurred more frequently as a right-sided unilateral tumour, which was not the case for SCOCPT $\left(X^{2}\right.$ Pearson $=20.0 ; \mathrm{df}=2 ; \mathrm{p}<0.001$; $\bullet$ Table 1). Average tumour size and volume of SCOCPT was significantly lower compared to SCOCHT, however, due to the low numbers this is only significant for size $\left(\mathrm{F}_{\mathrm{T} \text {-Test }}=5.4, \mathrm{p}=0.022\right.$; $\odot$ Table 1$)$. We also found that vimentin and chromogranin were the best parameters to distinguish between tumour types using immunohistochemistry.

Distribution of tumour stages according to the International Federation of Gynecology and Obstetrics (FIGO) classification is also shown in Table 1. Prognosis was very poor for both tumour types ( Fig. 2). Metastases of SCOCPT were found in the omentum $(n=8)$, lymph nodes $(n=6)$, the peritoneum $(n=5)$, intestine $(n=5)$, the liver $(n=3)$, lungs $(n=2)$ and breast $(n=2)$. All but 2 patients $(94.7 \%$; 36/38) underwent primary surgery that included bilateral $(\mathrm{n}=24)$ and unilateral $(\mathrm{n}=9)$ salpingo-ovariectomy, hysterectomy $(n=24)$, omentectomy $(n=17)$, lymphadenectomy $(n=14)$ and bowel surgery $(n=2)$. R0/R1 resection was achieved in $73.9 \%$ of the patients $(17 / 23)$ and $R 2$ resection in $26.1 \%(6 / 23)$. In three cases, additional surgical interventions were required to complete tumour resection; one case required interval debulking surgery and another case required secondlook surgery.

FIGO tumour stage proved to be a significant prognostic factor after classifying some cases based on the descriptions (logrank $_{\text {SCOCPT }}=18.2 ; \quad \mathrm{df}=3 ; \quad \mathrm{p}=0.0004 ; \quad \log$-rank $\quad$ sCOCHT $=12.6$; $\mathrm{df}=3 ; \mathrm{p}=0.006$ ). The result of the Kaplan-Meier analysis is shown in $\bullet$ Fig. 3. Recurrence rates even in patients with disease limited to the ovaries (stage Ia and Ib) were high. Of the 5 patients with SCOCPT staged as FIGO Ia or Ib and followed up, two (40\%; 2 / 5 ) had recurrence and died of the disease. 


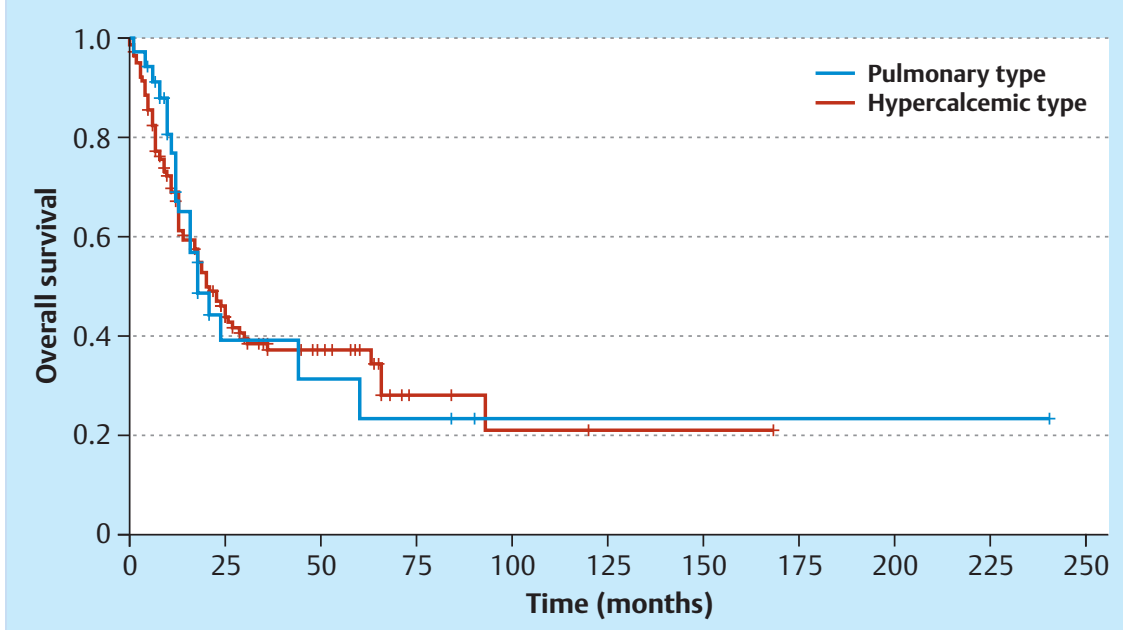

Fig. 2 Comparison of overall survival in patients with SCOCPT and SCOCHT (n. s.).

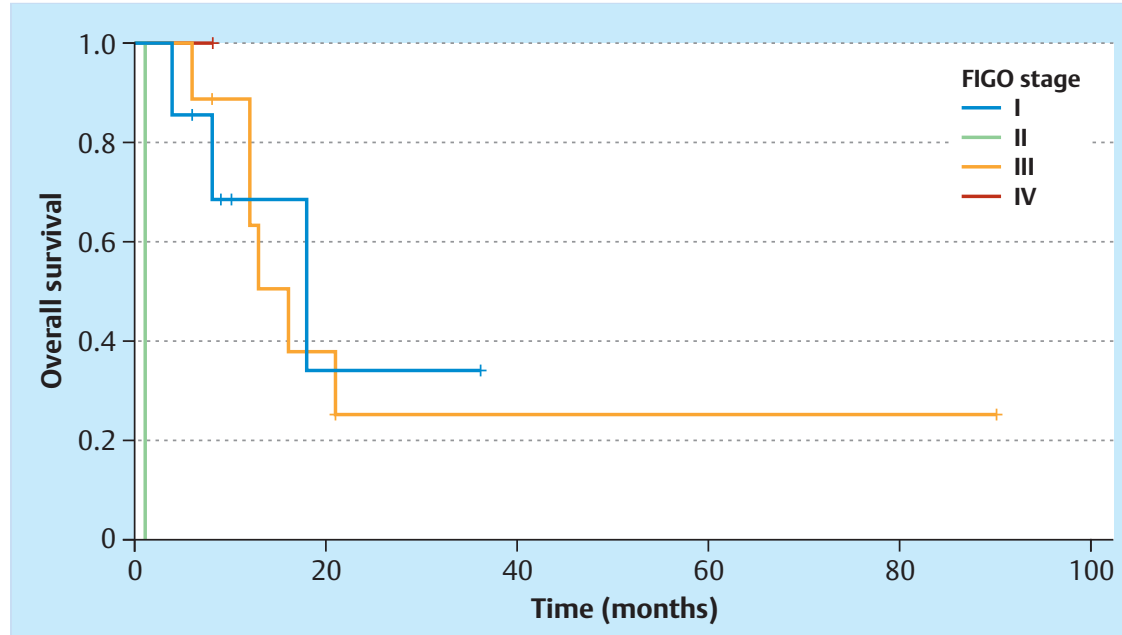

Fig. 3 Survival of patients with SCOCPT depending on tumour stage (FIGO; log-rank=18.2; $d f=3 ; p=0.0004)$.

SCOCPT was frequently found to be associated with other ovarian tumours which contrasts with SCOCHT $\left(X^{2}\right.$ Pearson $=45.6$; $\mathrm{df}=1$; $\mathrm{p}<0.001$ ). We investigated whether there were differences between "primary" SCOCPT, consisting solely of SCOCPT, and "secondary" SCOCPT, originating from or associated with other tumours. Information on associated tumours was available in 36 cases. We found no differences with respect to the parameters in Table 1, except for NSE, which was expressed in all cases of primary SCOCPT $(n=12)$ but only in $70 \%(n=10)$ of secondary SCOCPT $\left(X^{2}=4.2 ; p=0.041\right)$. There was a trend for primary SCOCPT to be found more frequently in early FIGO stages I and II ( $70 \% ; n=10)$, whereas $63.6 \%$ of secondary SCOCPT were found in the advanced FIGO stages III and IV.

$82.4 \%$ (28/34) of patients with SCOCPT received additional postoperative chemotherapy, complemented in 2 cases with radiotherapy. Chemotherapeutic regimens mainly consisted of cisplatinum or carboplatinum (83.9\%; $26 / 31$ ), etoposide (41.9\%; 13 / 31), alkylating agents (cyclophosphamide or iphosphamide [25.8\%; 8/31]), paclitaxel (19.4\%; 6/31), anthracyclines (doxorubicin $12.9 \%, 4 / 31)$, bleomycin $(12.9 \%, 4 / 31)$, vinca alkaloids (6.5\%; $2 / 31)$ and irinotecan $(6.5 \% ; 2 / 31)$. Using Kaplan-Meier analysis, we investigated the possible effect of various therapeutic approaches. We found a trend towards improved survival with the use of etoposide $(p=0.123)$ and anthracyclines $(p=0.154)$.
Radiotherapy and other types of chemotherapy failed to show such effects. Interestingly, the success of surgery as indicated by $\mathrm{R} 0 / \mathrm{R} 1$ resection did not prove to be a prognostic factor.

For SCOCHT we showed that administration of etoposide (logrank $=18.5 ; \mathrm{df}=1 ; \mathrm{p}<0.001$ ), cisplatinum or carboplatinum (logrank $=5.9 ; \mathrm{df}=1 ; \mathrm{p}=0.015$ ) or vinca alkaloids (log-rank=3.9; $\mathrm{df}=1 ; \mathrm{p}=0.047$ ) was associated with improved survival.

Recurrence was reported for $60 \%$ of patients with SCOCPT (18/ 30). Most frequently, local recurrence was reported as liver metastasis $(n=8)$, followed by brain metastasis $(n=7)$, bone metastasis $(n=5)$, lung $(n=3)$ and lymph node metastasis ( $n=3)$. Information on treatment for recurrence was available for 15 patients. Two patients (13.3\%) underwent surgery for recurrence, 10 (66.7\%) underwent chemotherapy and 9 received radiotherapy (60.0\%).

\section{Discussion \\ $\nabla$}

To the best of our knowledge, this is the most comprehensive analysis of SCOCPT to date. SCOCPT is a highly malignant tumour that affects women at a median age of 45 years. It has a poor prognosis even when diagnosed at an early stage. As noted previously by other authors, SCOCPT is frequently associated with oth- 
er tumours, which raises the question whether it may have a different pathogenesis [29,93]. Interestingly, we found that radical surgery was not as successful as in the treatment of common epithelial ovarian carcinomas. Moreover, we observed that vimentin and chromogranin allowed a good immunohistochemical distinction between SCOCPT and SCOCHT. Taking the limitations of this study into account (publication and selection bias; the fact that information on prognostic factors was incomplete in many reports or few details on surgical outcomes including residual tumour mass were available), we identified that treatment with etoposide and anthracyclines could be useful. This is very much in line with other reports which showed a beneficial effect of both drugs on small cell cancers originating from areas other than the ovaries $[100,101]$. Since patients with stage 1 disease have a better survival, surgery appears to be a reasonable option for these patients but not necessarily for patients in more advanced stages $[100,101]$. In contrast to other epithelial ovarian tumours, additional chemotherapy should not be omitted, even at very early stages. The conclusion is that treatment of SCOCPT should be based on the therapies used to treat other small cell carcinomas. The transfer of findings from other small cell carcinomas originating in other tissues could be useful. For example, it has been noted that somatostatin analogues can control symptoms and stabilise certain slow-growing tumours [102]. Integrating such approaches, perhaps even the use of oncolytic viruses, into the management of SCOCPT could help to improve patients' chances of survival [103].

As shown for SCOCHT, treatment with etoposide, cisplatinum or carboplatinum and vinca alkaloids may offer some benefits [4]. Again, the poor prognosis for this entity calls the concept of primary surgery in advanced stages of disease into question. Only patients with early stage disease appear to benefit from surgery [4]. Since it is very unlikely that there will be studies of these two rare tumour entities, the authors of case reports of these malignant tumours are requested to include all relevant information as this would allow future investigations to include multifactorial analysis.

\section{Conflict of Interest}

$\nabla$

None.

\section{References}

1 Rhiem K, Pfeifer K, Schmutzler RK et al. Risk-reducing surgery in women at risk for familial breast or ovarian cancer. Geburtsh Frauenheilk 2012; 72: 833-839

2 Tavassoli FA, Devilee P, eds. World Health Organization Classification of Tumours. Pathology and Genetics of Tumours of the Breast and Female Genital Organs. Lyon: IARC Press; 2003

3 Kupryjańczyk J. Neuroendocrine tumors of the ovary - a review. Verh Dtsch Ges Pathol 1997; 81: 253-259

4 Estel R, Hackethal A, Kalder $M$ et al. Small cell carcinoma of the ovary of the hypercalcaemic type: an analysis of clinical and prognostic aspects of a rare disease on the basis of cases published in the literature. Arch Gynecol Obstet 2011; 284: 1277-1282

5 Abeler V, Kjorstad KE, Nesland JM. Small cell carcinoma of the ovary. A report of six cases. Int J Gynecol Pathol 1988; 7: 315-329

6 Baeyens L, Amat S, Vanden Houte $K$ et al. Small cell carcinoma of the ovary successfully treated with radiotherapy only after surgery: case report. Eur J Gynaecol Oncol 2008; 29: 535-537

7 Barondeau J, Rodgers M, Braun L et al. Small cell ovarian carcinoma: a rare, aggressive tumor masquerading as constipation in a teenager with a fatal outcome. J Pediatr Hematol Oncol 2010; 32: e139-e141
8 Benito Reyes V, Martinez Lanao D, Lubrano Rosales A et al. Ovarian small cell carcinoma of hypercalcaemic-type: history of the disease in a patient who refused treatment. J Obstet Gynaecol 2011; 31: 354-356

9 Benrubi GI, Pitel P, Lammert N. Small cell carcinoma of the ovary with hypercalcemia responsive to sequencing chemotherapy. South Med J 1993; 86: 247-248

10 Bertoni F, Ferramosca B, Bacchini P. Small cell ovarian carcinoma with hypercalcemia: the role of the parathyroid hormone. G Clin Med 1983; 64: 564-570

11 Blatt J, Van Le L, Weiner T et al. Ovarian carcinoma in an adolescent with transgenerational exposure to diethylstilbestrol. J Pediatr Hematol Oncol 2003; 25: 635-636

12 Bourgain A, Acker O, Lambaudie E et al. Small cell carcinoma of the ovary of the hypercalcemic type revealed by a severe acute pancreatitis: about one case. Gynecol Obstet Fertil 2005; 33: 35-38

13 Brown H, Lane M. Cushing's and malignant carcinoid syndromes from ovarian neoplasm. Arch Intern Med 1965; 115: 490-494

14 Buono JP, Dechelotte P, Glowaczower E et al. Ploidy analysis in a case of ovarian small cell carcinoma with hypercalcemia. Ann Pathol 1995; 15: 134-137

15 Cannon PM, Smart CR, Wilson ML et al. Hypercalcemia with ovarian granulosa cell carcinoma. Rocky Mt Med J 1975; 72: 72-74

16 Chakraborty J, Biswas S, Sanyal S et al. Small cell carcinoma of ovary: a rare pathology. Indian J Pathol Microbiol 2007; 50: 322-324

17 Chan LC, Cheung A, Cheng D. Small cell carcinoma of the ovary associated with ins(10;5)(p13;q31q13). Cancer Genet Cytogenet 1994; 77 : 89-90

18 Chang DH, Hsueh S, Soong YK. Small cell carcinoma with neurosecretory granules arising in an ovarian dermoid cyst. Gynecol Oncol 1992; 46: 246-250

19 Chen F, Koenig C, Heller DS. A 26-year-old woman with right ovarian mass. Small cell carcinoma of ovary, hypercalcemic type. Arch Pathol Lab Med 2006; 130: e56-e58

20 Chen L, Dinh TA, Haque A. Small cell carcinoma of the ovary with hypercalcemia and ectopic parathyroid hormone production. Arch Pathol Lab Med 2005; 129: 531-533

21 Cheng Z, Yin H, Du J et al. Bilateral breast metastasis from small-cell carcinoma of the ovary. J Clin Oncol 2008; 26: 5129-5130

22 Christin A, Lhomme C, Valteau-Couanet D et al. Successful treatment for advanced small cell carcinoma of the ovary. Pediatr Blood Cancer 2008; 50: $1276-1277$

23 Dharan $M$. Intraoperative cytology of small cell carcinoma of the ovary with hypercalcemia. A case report. Acta Cytol 1993; 37: 61-66

24 Di Vagno G, Melilli GA, Cormio G et al. Large-cell variant of small cell carcinoma of the ovary with hypercalcaemia. Arch Gynecol Obstet 2000; 264: $157-158$

25 Dickersin GR, Kline IW, Scully RE. Small cell carcinoma of the ovary with hypercalcemia: a report of eleven cases. Cancer 1982; 49: 188-197

26 Distelmaier F, Calaminus G, Harms D et al. Ovarian small cell carcinoma of the hypercalcemic type in children and adolescents: a prognostically unfavorable but curable disease. Cancer 2006; 107: 2298-2306

27 Donato G, Conforti F, Zuccala V et al. Large cell variant ovarian small cell carcinoma: case report. Ultrastruct Pathol 2008; 32: 206-210

28 Dykgraaf $R H$, de Jong $D$, van Veen $M$ et al. Clinical management of ovarian small-cell carcinoma of the hypercalcemic type: a proposal for conservative surgery in an advanced stage of disease. Int J Gynecol Cancer. 2009; 19: 348-353

29 Eichhorn JH, Young RH, Scully RE. Primary ovarian small cell carcinoma of pulmonary type. A clinicopathologic, immunohistologic, and flow cytometric analysis of 11 cases. Am J Surg Pathol 1992; 16: 926-938

30 Ferrera PC, Whitman MC. Ovarian small cell carcinoma: a rare neoplasm in a 15-year-old female. Pediatr Emerg Care 2000; 16: 170-172

31 Fignon A, Fetissof F, Calais $G$ et al. Small cell carcinoma of the ovary. A clinical and anatomo-pathologic entity. J Gynecol Obstet Biol Reprod (Paris) 1993; 22: 372-378

32 Florell SR, Bruggers CS, Matlak M et al. Ovarian small cell carcinoma of the hypercalcemic type in a 14 month old: the youngest reported case. Med Pediatr Oncol 1999; 32: 304-307

33 Forster C, Ostertag H, Schmitt J et al. Small cell carcinoma of the ovary, hypercalcemic type. A case report with immunohistochemical, ultrastructural and cytophotometric analysis and review of the literature. Gen Diagn Pathol 1997; 142: 365-370 
34 Fukunaga M, Endo Y, Miyazawa Y et al. Small cell neuroendocrine carcinoma of the ovary. Virchows Arch 1997; 430: 343-348

35 Fukunaga M, Endo Y, Nomura K et al. Small cell carcinoma of the ovary: a case report of large cell variant. Pathol Int 1997; 47: 250-255

36 Grandjean M, Legrand L, Waterkeyn M et al. Small cell carcinoma of pulmonary type inside a microinvasive mucinous cystadenocarcinoma of the ovary: a case report. Int J Gynecol Pathol 2007; 26: 426-431

37 Hamilton S, Beattie GJ, Williams AR. Small cell carcinoma of the ovary: a report of three cases and review of the literature. J Obstet Gynaecol 2004; 24: 169-172

38 Harada H, Kinoshita T, Fujii S et al. Small cell carcinoma arising in postoperative ovary after enucleation for dermoid cysts; a case report. Jpn J Clin Radiol 2003; 48: 890-893

39 Harrison ML, Hoskins P, du Bois A et al. Small cell of the ovary, hypercalcemic type - analysis of combined experience and recommendation for management. A GCIG study. Gynecol Oncol 2006; 100: 233-238

40 Hirabayashi $K$, Yasuda M, Osamura RY et al. Ovarian nongestational choriocarcinoma mixed with various epithelial malignancies in association with endometriosis. Gynecol Oncol 2006; 102: 111-117

41 Holtz G, Johnson Jr. TR, Schrock ME. Paraneoplastic hypercalcemia in ovarian tumors. Obstet Gynecol 1979; 54: 483-487

42 Idei Y, Kitazawa S, Fujimori T et al. Ovarian small cell carcinoma with K-ras mutation: a case report with genetic analysis. Hum Pathol 1996; 27: 77-79

43 Ikota H, Kaneko K, Takahashi S et al. Malignant transformation of ovarian mature cystic teratoma with a predominant pulmonary type small cell carcinoma component. Pathol Int 2012; 62: 276-280

44 Inadome Y, Shibata T, Suzuki Ket al. Hypercalcemic-type ovarian small cell carcinoma with unique CD34 expression. Pathol Int 2009; 59: 766 768

45 Isonishi S, Nishii H, Saitou $M$ et al. Small cell carcinoma of the ovary: clinical and biological study. Int J Clin Oncol 2008; 13: 161-165

46 Kanwar VS, Heath J, Krasner CN et al. Advanced small cell carcinoma of the ovary in a seventeen-year-old female, successfully treated with surgery and multi-agent chemotherapy. Pediatr Blood Cancer 2008; 50: $1060-1062$

47 Kawasaki F, Takai N, Narahara $H$ et al. A rare case of bilateral small cell carcinoma of the ovary diagnosed during pregnancy. Int J Clin Oncol 2000; 5: 200-203

48 Kedzia H. Small cell carcinoma of the ovary. Ginekol Pol 1994; 65: 146152

$49 \mathrm{Kim}$ J, Kim Y, Seong $\mathrm{H}$ et al. Primary small cell carcinoma of the ovary and the long-term survival after systemic chemotherapy. Korean J Med 2007; 72: 563-567

50 Kira $N$, Takai $N$, Ishii $T$ et al. Ovarian small cell carcinoma complicated by carcinomatous meningitis. Rare Tumors 2012; 4: e26

51 Koven BJ, Dollinger MR, Nadel MS. Response to actinomycin D of malignant carcinoid arising in an ovarian teratoma. Am J Obstet Gynecol 1968; 101: 267-268

52 Krivak T, Alagoz T. Small cell ovarian cancer: A case report and review of the literature. The Female Patient 2002; 12: 3-16

53 Lamovec J, Bracko M, Cerar O. Familial occurrence of small-cell carcinoma of the ovary. Arch Pathol Lab Med 1995; 119: 523-527

54 Lee J, Kim H, Son Yet al. Small cell carcinoma of the ovary of pulmonary type: immunohistochemical and ultrastructural study. A Case Report. 대부종콜포회지 1998; 9: 307-311

55 Lifschitz-Mercer B, David R, Dharan $M$ et al. Small cell carcinoma of the ovary: an immunohistochemical and ultrastructural study with a review of the literature. Virchows Arch A Pathol Anat Histopathol 1992; 421: $263-270$

56 Lim SC, Choi SJ, Suh CH. A case of small cell carcinoma arising in a mature cystic teratoma of the ovary. Pathol Int 1998; 48: 834-839

57 Lo Re G, Canzonieri V, Veronesi A et al. Extrapulmonary small cell carcinoma: a single-institution experience and review of the literature. Ann Oncol 1994; 5: 909-913

58 Longy M, Toulouse C, Mage P et al. Familial cluster of ovarian small cell carcinoma: a new Mendelian entity? J Med Genet 1996; 33: 333-335

59 Malfetano JH, Degnan E, Florentin R. Para-endocrine hypercalcemia and ovarian small cell carcinoma. N Y State J Med 1990; 90: 206-207

60 Martinez-Borges AR, Petty JK, Hurt G et al. Familial small cell carcinoma of the ovary. Pediatr Blood Cancer 2009; 53: 1334-1336

61 McCormick TC, Muffly T, Lu G et al. Aggressive small cell carcinoma of the ovary, hypercalcemic type with hypercalcemia in pregnancy, treated with conservative surgery and chemotherapy. Int J Gynecol Cancer 2009; 19: 1339-1341
62 McDonald JM, Karabakhtsian RG, Pierce HH et al. Small cell carcinoma of the ovary of hypercalcemic type: a case report. J Pediatr Surg 2012; 47: 588-592

63 Mebis J, De Raeve H, Baekelandt M et al. Primary ovarian small cell carcinoma of the pulmonary type: a case report and review of the literature. Eur J Gynaecol Oncol 2004; 25: 239-241

64 Meganck G, Moerman P, De Schrijver D et al. A non-diploid, small cell carcinoma of the ovary of the hypercalcemic type. Int J Gynecol Cancer 1998; 8: 430-433

65 Montalto SA, Gupta A, Hakmi A et al. Small cell carcinoma of the ovary: hypercalcaemic type. J Obstet Gynaecol 2011; 31: 199-200

66 Nelsen LL, Muirhead DM, Bell MC. Ovarian small cell carcinoma, hypercalcemic type exhibiting a response to high-dose chemotherapy. S D Med 2010; 63: 375-377

67 Niimi S, Kiyokawa T, Takakura S et al. Recurrent small cell carcinoma of the ovary treated with docetaxel: A case report. Int J Gynecol Cancer 2006; 16: 1944-1946

68 Patsner B, Piver MS, Lele SB et al. Small cell carcinoma of the ovary: a rapidly lethal tumor occurring in the young. Gynecol Oncol 1985; 22: 233-239

69 Peccatori F, Bonazzi C, Lucchini V et al. Primary ovarian small cell carcinoma: four more cases. Gynecol Oncol 1993; 49: 95-99

70 Powell JL, McAfee RD, McCoy RC et al. Uterine and ovarian conservation in advanced small cell carcinoma of the ovary. Obstet Gynecol 1998 91: 846-848

71 Pruett KM, Gordon AN, Estrada R et al. Small-cell carcinoma of the ovary: an aggressive epithelial cancer occurring in young patients. Gynecol Oncol 1988; 29: 365-369

72 Rana S, Warren BK, Yamada SD. Stage IIIC small cell carcinoma of the ovary: survival with conservative surgery and chemotherapy. Obstet Gynecol 2004; 103: 1120-1123

73 Rasmussen KL, Jensen ML, Nielsen KM et al. Small cell carcinoma of the ovary diagnosed in early pregnancy. Acta Obstet Gynecol Scand 1991; 70: 377-379

74 Reckova M, Mego M, Rejlekova K et al. Small-cell carcinoma of the ovary with breast metastases: a case report. Klin Onkol 2010; 23: 43-45

75 Reed WC. Small cell carcinoma of the ovary with hypercalcemia: report of a case of survival without recurrence 5 years after surgery and chemotherapy. Gynecol Oncol 1995; 56: 452-455

76 Rosenbaum T, Gartner J, Korholz D et al. Paraneoplastic limbic encephalitis in two teenage girls. Neuropediatrics 1998; 29: 159-162

77 Rovithi M, Pallis AG, Kalykaki A et al. Small cell ovarian cancer in adolescents: report of two cases and review of the literature. Case Rep Med 2011; 2011: 749516

78 Rund CR, Fischer EG. Perinuclear dot-like cytokeratin 20 staining in small cell neuroendocrine carcinoma of the ovary (pulmonary-type). Appl Immunohistochem Mol Morphol 2006; 14: 244-248

79 Saika N, Malhotra P, Khandelwal $N$ et al. Small cell carcinoma of the ovary presenting as bone marrow metastasis: a rare presenting feature. Indian J Pathol Microbiol 2005; 48: 402-404

80 Saitoh-Sekiguchi M, Nakahara K, Kojimahara T et al. Complete remission of ovarian small cell carcinoma treated with irinotecan and cisplatin: a case report. Anticancer Res 2007; 27: 2685-2687

81 Schleef J, Wagner A, Kleta R et al. Small-cell carcinoma of the ovary of the hypercalcemic type in an 8-year-old girl. Pediatr Surg Int 1999; 15: 431-434

82 Schultz KA, Sencer SF, Messinger Y et al. Pediatric ovarian tumors: a review of 67 cases. Pediatr Blood Cancer 2005; 44: 167-173

83 Schweiger LM, Hsiang HY. Pathological case of the month. Acute symptomatic hypercalcemia associated with ovarian small cell carcinoma. Arch Pediatr Adolesc Med 2002; 156: 83-84

84 Selvaggi SM. Small-cell carcinoma of the ovary in peritoneal fluid. Diagn Cytopathol 1994; 11: 266-270

85 Senekjian EK, Weiser PA, Talerman A et al. Vinblastine, cisplatin, cyclophosphamide, bleomycin, doxorubicin, and etoposide in the treatment of small cell carcinoma of the ovary. Cancer 1989; 64: 1183-1187

86 Sholler GL, Luks F, Mangray S et al. Advanced small cell carcinoma of the ovary in a pediatric patient with long-term survival and review of the literature. J Pediatr Hematol Oncol 2005; 27: 169-172

87 Shrimali RK, Correa PD, Reed NS. Dose-dense and dose-intense chemotherapy for small cell ovarian cancer: 2 cases and review of literature. Med Oncol 2011; 28: 766-770

88 Stephens B, Anthony SP, Han H et al. Molecular characterization of a patient's small cell carcinoma of the ovary of the hypercalcemic type. J Cancer 2012; 3: 58-66 
89 Sundersingh S, Rajasundaram S, Majhi U. Bilateral adrenal metastases from bilateral small cell neuroendocrine carcinoma of the ovary. Indian J Surg 2003; 65: 373-375

90 Suzuki N, Kameyama K, Hirao T et al. A case of pulmonary type of ovarian small cell carcinoma. J Obstet Gynaecol Res 2007; 33: 203-206

91 Taraszewski R, Rosman PM, Knight CA et al. Small cell carcinoma of the ovary. Gynecol Oncol 1991; 41: 149-151

92 Tewari K, Brewer C, Cappuccini F et al. Advanced-stage small cell carcinoma of the ovary in pregnancy: long-term survival after surgical debulking and multiagent chemotherapy. Gynecol Oncol 1997; 66: 531534

93 Tsolakidis D, Papanikolaou A, Ktenidis K et al. Primary ovarian small cell carcinoma of pulmonary type with enlarged paraaortic lymph node masses: a case report and review of the literature. Eur J Gynaecol Oncol 2012; 33: 312-315

94 Ulbright TM, Roth LM, Stehman FB et al. Poorly differentiated (small cell) carcinoma of the ovary in young women: evidence supporting a germ cell origin. Hum Pathol 1987; 18: 175-184

95 Walt H, Hornung R, Fink D et al. Hypercalcemic-type of small cell carcinoma of the ovary: characterization of a new tumor line. Anticancer Res 2001; 21: 3253-3259

96 Wynn D, Everett GD, Boothby RA. Small cell carcinoma of the ovary with hypercalcemia causes severe pancreatitis and altered mental status. Gynecol Oncol 2004; 95: 716-718
97 Yi S, Sohn W, Park H et al. A case of small cell carcinoma of pulmonary type of ovary associated with huge mucinous cystadenocarcinoma. Korean J Obstet Gynecol 2008; 51: 777-783

98 Young RH, Goodman A, Penson RT et al. Case records of the Massachusetts General Hospital. Case 8-2010. A 22-year-old woman with hypercalcemia and a pelvic mass. N Engl J Med 2010; 362: 1031-1040

99 Young RH, Oliva E, Scully RE. Small cell carcinoma of the ovary, hypercalcemic type. A clinicopathological analysis of 150 cases. Am J Surg Pathol 1994; 18: 1102-1116

100 Strosberg JR, Coppola D, Klimstra DS et al. The NANETS consensus guidelines for the diagnosis and management of poorly differentiated (high-grade) extrapulmonary neuroendocrine carcinomas. Pancreas 2010; 39: 799-800

101 Hann CL, Rudin CM. Management of small-cell lung cancer: incremental changes but hope for the future. Oncology (Williston Park) 2008; 22: 1486-1492

102 Reidy DL, Tang $L H$, Saltz LB. Treatment of advanced disease in patients with well-differentiated neuroendocrine tumors. Nat Clin Pract Oncol 2009; 6:143-152

103 Hartkopf $A D$, Fehm T, Wallwiener $M$ et al. Oncolytic viruses to treat ovarian cancer patients - a review of results from clinical trials. Geburtsh Frauenheilk 2012; 72: 132-136 